Applied Economics

\title{
Does listed real estate behave like direct real estate? Updated and broader evidence
}

\section{Martin Hoesli \& Elias Oikarinen}

To cite this article: Martin Hoesli \& Elias Oikarinen (2021) Does listed real estate behave like direct real estate? Updated and broader evidence, Applied Economics, 53:26, 3023-3042, DOI: 10.1080/00036846.2020.1870921

To link to this article: https://doi.org/10.1080/00036846.2020.1870921

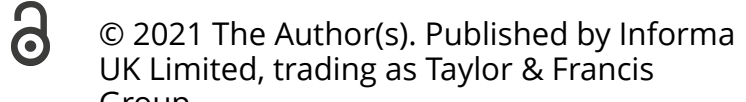
Group.

\section{Published online: 21 Mar 2021.}

Submit your article to this journal $\pi$

Џ Article views: 598

Q View related articles

View Crossmark data $\nearrow$ 


\title{
Does listed real estate behave like direct real estate? Updated and broader evidence
}

\author{
Martin Hoesli ${ }^{\mathrm{a}, \mathrm{b}}$ and Elias Oikarinen ${ }^{\mathrm{c}, \mathrm{d}, \mathrm{e}}$ \\ ${ }^{\mathrm{a} G e n e v a}$ Finance Research Institute and Swiss Finance Institute, University of Geneva, Geneva, Switzerland; ${ }^{b}$ Business School, University of \\ Aberdeen, Aberdeen, UK; ' 'Department of Economics, Accounting and Finance, University of Oulu, Oulu, Finland; dDepartment of Built \\ Environment, Aalto University, Helsinki, Finland; 'Department of Economics, University of Turku, Turku, Finland
}

\section{ABSTRACT}

This study investigates a question relevant to many investors: do the broad Real Estate Investment Trust (REIT) return characteristics reflect those of the broad direct real estate markets. The paper makes several contributions to the literature in addition to using more recent data: (1) we use data for six countries (Australia, France, Germany, Netherlands, the U.K., and the U.S.); (2) we estimate both country-specific and panel models to increase the reliability and generalizability of the analysis; (3) we estimate a structural vector autoregressive model to be able to better and more reliably interpret the various shocks in the system; and (4) we investigate the effects of global liquidity shocks, among other shocks. Our results indicate that over the mid to long horizon, broad REIT and direct returns have similar characteristics and are highly correlated at the panel level. Also, the two types of exposure to real estate exhibit similar reactions to economic shocks. Thus, the paper makes a case that investors do not necessarily need to worry much about compositional effects when aiming to track broad international direct market performance by investing in listed real estate.

\section{KEYWORDS}

Listed real estate; REITs; portfolio diversification; panel regression

\section{JEL CLASSIFICATION}

R33; G11; G12

\section{Introduction}

Real estate has been shown to provide significant diversification benefits in a portfolio containing financial assets but also other types of alternative assets (Hoesli, Lekander, and Witkiewicz 2004; Lizieri 2013; Pagliari 2017; Delfim and Hoesli 2019). Against this background, the question of whether listed real estate behaves as private real estate is an important one for investors. If listed and direct real estate returns are generated by a common 'real estate factor' over the long horizon, then listed real estate securities - at least when leverage in controlled for are expected to provide similar returns and return volatilities and the same diversification benefits as direct real estate in a mixed-asset portfolio of a longhorizon buy-and-hold investor, such as a pension fund or a sovereign wealth fund. Obviously, listed real estate investments would then constitute an appealing avenue for investing in the asset class given the flexibility, liquidity, and low transaction costs of such investments.

It could be expected that the returns and risks of privately traded direct investments and of securities that are based on direct assets are alike, at least in the long run and after catering for the effects of leverage. After all, the security cash flows are generated from the underlying direct assets (i.e., the expected cash flows and their volatility should be similar). Nevertheless, due to factors such as higher liquidity and lower transaction costs of assets traded in public markets, the returns on listed securities may deviate from those on private assets. In particular, a lower liquidity premium and lower transaction costs could induce a lower required (and therefore also expected) return on listed assets. Also the diversification benefits offered by securities versus direct assets can differ, at least in the relatively short term, possibly affecting the required rates of return. In addition, it is well known that the public asset markets are more informationally efficient than their private counterparts. Therefore, it is essentially an empirical question to examine whether the trading 'platform' influences the asset returns and return volatilities, and hence whether listed and direct real estate are akin. 
Given the importance of the topic for numerous types of investors, it is not surprising that the relationship between listed and direct real estate has been investigated intensively in the literature. Regarding public market performance, these studies have typically relied on data for listed real estate investment trusts (REITs). Over the short term, REIT returns correlate strongly with stock returns rather than with real estate returns (MacKinnon and Al Zaman 2009; Hoesli and Oikarinen 2012). However, it has been shown that over the longer horizon - at least when controlling for property type and the leverage of REITs - listed real estate returns tend to co-move with the real estate market and the correlation with stock returns is weaker (e.g., Hoesli and Oikarinen 2012). The observed discrepancy between shortand long-term correlations is not surprising given the notable frictions in direct real estate markets that tend to make direct market price adjustments sluggish. Such sluggish adjustments can cause lead-lag relations between REIT and direct returns that diminish the short-term correlations ( $\mathrm{Li}$, Mooradian, and Yang 2009; Oikarinen, Hoesli, and Serrano 2011; Yunus, Hansz, and Kennedy 2012; Hoesli, Oikarinen, and Serrano 2015).

The evidence on the similarity of returns and their volatilities is more mixed. In Pagliari, Scherer, and Monopoli (2005) and Hoesli and Oikarinen (2016), the mean returns and return volatilities of REITs and direct real estate do not differ in a statistically significant manner. Riddiough, Moriarty, and Yeatman (2005), in turn, report a three percentage point difference between REIT and direct returns. Ling and Naranjo (2015) provide evidence of the REIT market outperforming the private real estate market for some sectors, while direct investments provide higher returns in other markets. The latter two papers do not test for the significance of the differences, though. All of these studies aim to carefully control for property type and leverage.

While the trend in academic research has been towards using more and more narrowly defined real estate categories when comparing the return characteristics, we move in the opposite direction. That is, our aim is to ask a question that is relevant to many investors: do the broad REIT index return characteristics generally reflect those of the broad direct real estate markets? If the answer is yes, an investor does not necessarily need to concentrate on the geographic and sectoral mixes in order to track broad private market performance by REITs. Hence, the aim of this paper is different from most of the recent studies on the topic: we do not aim to consider the sectoral mix, but rather explore whether, notwithstanding the effect of leverage, investing in the REIT index generates similar return characteristics (and therefore substitutability) as those of the direct real estate portfolio of institutional investors in that country.

Relative to the extant literature on how closely listed real estate returns reflect direct returns, this paper makes multiple contributions in addition to using more recent data and considering the 'broad view'. First, we use data for more countries than previous studies - altogether six (Australia, France, Germany, Netherlands, the U.K., and the U.S.). Second, we estimate both country-specific and panel models to increase the reliability and generalizability of the analysis. Third, we estimate a structural vector autoregressive model to better and more reliably interpret the various economic shocks in the system. This method helps identifying which shocks cause similar or different reactions on the two types of real estate exposure and has not been used in the earlier studies on the topic.

In addition to the listed and direct real estate indexes, we incorporate in the analysis a number of fundamental variables that are expected to influence and have been found to affect listed and direct real estate returns and that can be utilized to identify the structural (i.e., more reliably identifiable) economic shocks. These variables incorporate a global liquidity variable, the inclusion of which is another novelty of this paper and is done in order to investigate the influences of global liquidity shocks. We use annual data for the six countries for the period 1998-2017 and control for the leverage of listed investments.

Our results indicate that over the mid to long horizon, REIT and direct real estate returns and return volatilities are similar at the broad level. The correlation between the returns is high over the long horizon whether or not one controls for the leverage of REITs. Also, the two types of exposure exhibit similar reactions to economic shocks. Thus, the paper makes a case that the two types of 
exposure to the asset class are largely substitutable over the long term and that investors generally do not need to worry much about compositional effects when aiming to track broad direct market performance with REITs. Interestingly, while we observe positive global liquidity shocks to increase both listed and direct real estate values, positive real estate-related shocks in turn increase the liquidity.

The remainder of the paper is structured as follows. We next present the methods, before discussing the data. The following section contains a discussion of the results. A final section contains concluding remarks.

\section{Methods}

In the empirical analysis, we use simple F-statistics and investigate correlation structures of listed and direct real estate investments, as well as estimate pairwise regression models and a structural panel vector-autoregressive (SVAR) model to study the return dynamics. Moreover, cointegration tests are conducted based on the regression models. Throughout the analysis, log returns are used, i.e., returns are computed as first differences of broad public and private real estate total return indexes in the natural $\log$ form.

Similar to Pagliari, Scherer, and Monopoli (2005) and Hoesli and Oikarinen (2016), we apply the conventional F-test to study the equality of listed and direct real estate returns and volatilities. A novelty compared with earlier studies is the use of panel tests: we conduct tests including all six countries together as a panel in addition to investigating each country separately. The panel approach enables us to consider the broader view.

A complication that weakens the reliability of the conventionally used F-test is that the F-test results can be highly dependent on the ending and starting dates of the sample period. Given the observed lead-lag relations between listed and direct real estate returns and the tendency of direct market prices to react to changes sluggishly, this can be problematic particularly if the starting or ending period represents an abnormal time period, such as a financial crisis time or a period with otherwise notable shocks in the market fundamentals. Also, (abnormally) prominent cycles, such as the one due to the global financial crisis (GFC) of the 2000s, and thereby unusually high return volatility in the sample period, increases the likelihood of accepting the null of similar returns in the F-test.

Hence, we estimate panel regression models that are less vulnerable to such complications - to test for the long-term relationship between the returns. In these regression models (the natural log of) the REIT total return index (REIT) is the left-hand-side variable, while the broad direct market return index (MSCI) is the right-hand side variable:

$$
\operatorname{REIT}_{i, t}=\alpha_{i}+\beta_{i} M_{S C I} I_{i, t}+\varepsilon_{i, t}
$$

Given that direct market returns can be endogenous with respect to REIT returns, we apply the Panel Fully Modified OLS (FMOLS) estimator of Pedroni $(2000,2001)$ in these regressions. While the conventional fixed-effects and random-effects OLS estimators can exhibit endogeneity bias, the FMOLS estimator is consistent even in the presence of endogenous regressors and endogeneity arising due to possible omitted variables (Pedroni 2001, 2007). We report regression results for both the pooled FMOLS estimator (PFMOLS) that does not allow for heterogeneity across the countries other than the country-specific fixed-effects (i.e., $\beta_{i}$ is the same for all countries $i$ ) and the FMOLS mean-group estimator (MG-FMOLS) that allows for heterogeneity in the parameter estimate across countries for the direct market return index too (i.e., $\beta_{i}$ varies across $i$ ). In contrast to the fixedeffects OLS estimator, the FMOLS estimators are also super-consistent in the presence of nonstationary but cointegrated data.

We then test for cointegration between the return indexes using the CIPS panel unit root test (Pesaran 2007), and test for the hypothesis that $\beta_{i}=$ 1 with the Wald F-test both for individual countries and at the panel level. This provides an additional advantage over the simple F-test on returns: a oneto-one cointegrating relation between two asset return indexes would indicate that the equivalence of mean returns is not just a coincidence that is likely to vanish in the future, but that there are strong economic forces keeping the series together in the long run due to an equilibrium relation between the series. This analysis is less prone to 
the potential complications caused by sample period timing: while the F-test is to a major extent based on the starting and ending values of return indexes, the tests grounded on the regression models are based on the relationship between the return indexes during the whole sample period. Moreover, the concept of cointegration allows for even large temporary deviations from a long-run equilibrium relation, and cointegration of return indexes would indicate that the return correlation approaches one as the assumed investment horizon is extended. Cointegration analysis has been previously used to investigate the long-term relationship between the stock market and listed or direct real estate, or among real estate markets, as well (Lin and Fuerst 2014; Yunus 2018).

Any observed comovement between REIT and direct market returns may be an indirect effect of economic factors, not due to a pure influence of the markets on each other; hence, it is interesting to study the influences of shocks in various economic factors on listed and direct real estate returns. Vector autoregressive (VAR) models provide a useful tool to conduct such investigations. In particular, the investigation of impulse response functions derived from VAR models allows for the comparison of the reaction patterns of returns to various shocks. The analysis is particularly interesting if the shocks can be given economic interpretations in that the model restrictions are based on economic arguments and the observed impulse responses of the fundamental economic variables support the interpretation of the shock origin. In such case, the model may be called SVAR.

Given our aim to study the broader market dynamics, we estimate a panel SVAR model. This also enables us to have enough observations for a more reliable analysis, given the limited number of observations for individual countries. The estimated SVAR includes an error-correction mechanism that takes account of the observed stationary long-term relations (i.e., cointegration) between the return indexes. Although SVAR models have been used to study the effects of shocks in economic fundamentals on asset returns (e.g., Yang et al. 2018), such modelling approach has not been previously used to compare the REIT and direct real estate dynamics.
In panel (S)VAR models, the presence of lagged dependent variables on the right-hand side of the system of equations causes the well-known Nickell bias (Nickell 1981). Therefore, we estimate the SVAR model with the Arellano and Bover (1995) GMM estimator that removes the bias. To identify the shocks for the purposes of impulse response analysis, only short-run restrictions are used in this analysis. The restrictions applied to identify the shocks are discussed in section 4.

All the panel analyses give equal weight to each of the six markets included in the analysis. Hence, the results from these analyses basically concern a portfolio with equal weights for each of the six countries.

\section{Data}

Given that much of the extant empirical evidence concerns the U.S. and to a lesser extent the U.K. (exceptions include Hoesli and Oikarinen 2012; Yunus, Hansz, and Kennedy 2012; Haran et al. 2013), our objective is to include as many countries as possible for which sufficient data are available. The available data allows us to include annual data for six countries: Australia, France, Germany, Netherlands, the U.K., and the U.S. The set of countries is highly representative as they account for over $70 \%$ of the free float of REIT market capitalization in developed countries. For direct real estate, we use the MSCI indexes of institutional real estate holdings, while for listed investments we use the EPRA/NAREIT indexes. The time period for our data is from 1998 to 2017. As the aim is specifically to study the long-term relationships, the use of annual data should not cause complications: within year quarterly or monthly variations in the returns are not of notable relevance for longhorizon buy-and-hold investors. The annual nature of the data obviously restricts the number of observations per country, but the use of panel data diminishes this complication: the panel includes 120 observation points ( 20 for each country).

REIT returns are, by construction, net of portfolio-level management fees. However, such fees are not readily deducted from MSCI returns. Thus, we deduct portfolio-level management costs from the MSCI data to make the returns comparable. Following Riddiough, Moriarty, and Yeatman 
(2005) and Ling and Naranjo (2015), we assume 80 bps management fees. This assumption also is well in line with the management fees reported for pension funds in a range of countries by Andonov, Eichholtz, and Kok (2015).

Direct returns are desmoothed using a desmoothing parameter of 0.5 (Geltner et al. 2007), and REIT returns are unlevered using the actual leverage of constituent companies in the EPRA/NAREIT indexes for each country. Similar to Pagliari, Scherer, and Monopoli (2005) and Hoesli and Oikarinen (2016), we compute the unlevered REIT returns using the formula that is based on the well-known proposition of Modigliani and Miller (1958):
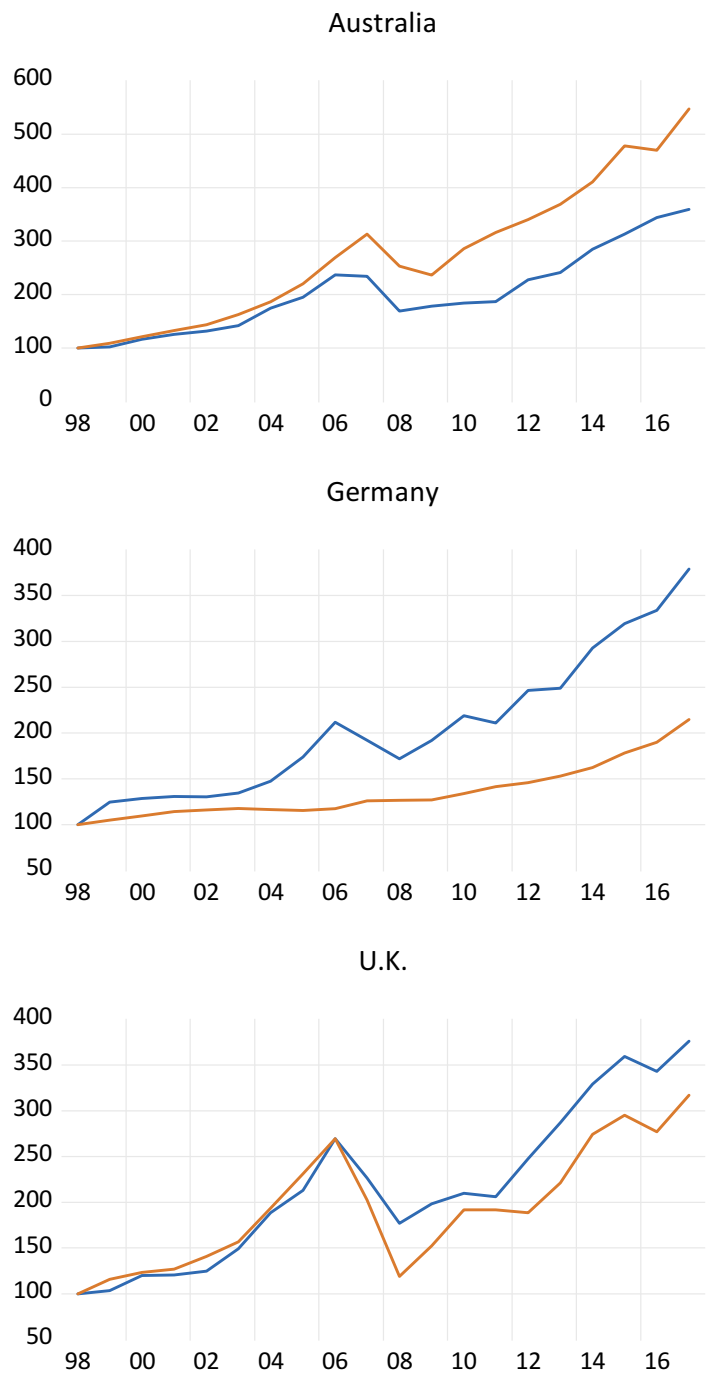

$$
r_{u i t}=r_{e i t}\left(1-L T V_{i t}\right)+r_{d i t} L T V_{i t}
$$

where $r_{\text {uit }}=$ the unlevered REIT return in country $i$ in period $t, r_{e i t}=$ the return on equity of REITs in country $i$ in period $t, r_{d i t}=$ the cost of debt in country $i$ in period $t$, and $L T V_{i t}=$ the REIT loanto-value ratio in country $i$ in period $t$. The cost of debt applied in the computations is the BBB rated corporate bond yield for the corresponding country sourced from Macrobond.

Figure 1 shows the indexes of direct real estate (net of management fees) and unlevered listed investments. The indexes for the two types of exposure move by and large in line, except for Australia, Germany, and the U.S. In Australia,
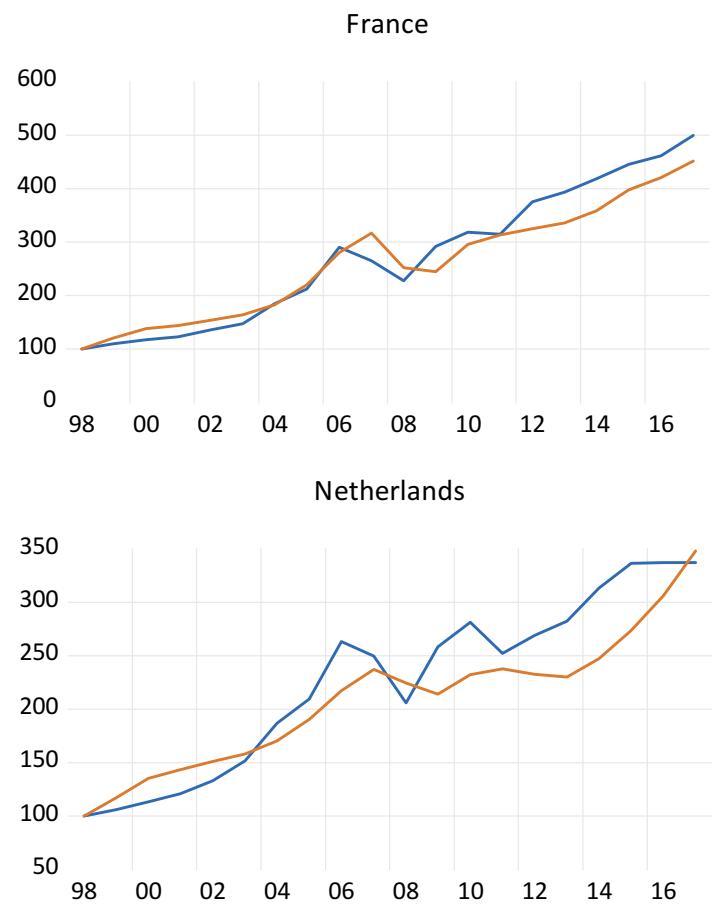

U.S.

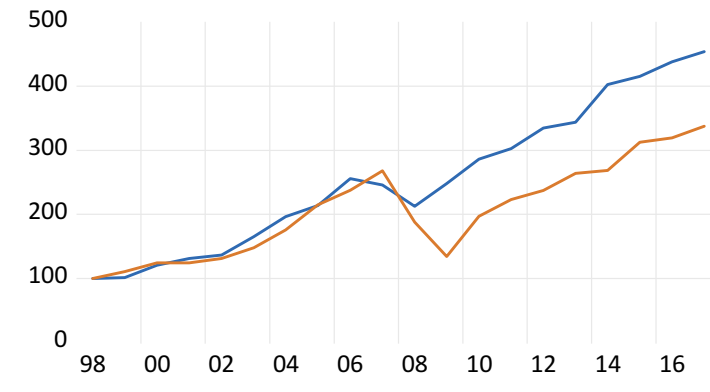

— Listed Unlevered — Direct

Figure 1. Indexes of unlevered listed and direct real estate (net of management costs). 
the listed market suffered heavily during the GFC and was slow in recovering thereafter, whereas in the U.S. the relationship between listed and direct market returns since the GFC is just the opposite. In Germany, the listed market outperformed the direct market as a consequence of the much higher weight of the residential sector in the listed index than in the direct index. Germany is considerably different from the other markets considered in terms of the discrepancy in property type mix between direct and listed indexes.

Based on theoretical considerations (i.e., the basic asset pricing formula) and previous empirical evidence (Hoesli and Oikarinen 2012; Hoesli, Oikarinen, and Serrano 2015), the set of economic fundamentals incorporated in the SVAR model includes GDP, the risk premium, the short-term risk-free interest rate, and consumer sentiment. GDP measures growth in the real economy that influences the demand for real estate space, and thereby the expected rental cash flows. The default risk premium $(D)$, which is defined as the spread between the low-grade corporate bond benchmark yield (BBB, Moody's) and the 10-year government bond yield, is expected to influence the risk premium component of the discount factor (i.e., the required rate of return) in the asset pricing formula. The short-term interest rate $(R)$, too, can be assumed to affect the discount rate and is measured by the three-month interbank rate. Finally, we use confidence indicators from national consumer opinion surveys to capture the consumer sentiment that is expected to predict future economic growth, and thereby rental growth. The sentiment component of the confidence indicators can be regarded as the component that is unrelated to prevailing economic fundamentals. Therefore, similar to, e.g., Ling, Naranjo, and Scheick (2014) and Hoesli, Oikarinen, and Serrano (2015), we regress the differenced confidence indicator on the three economic fundamentals (differenced) mentioned above and use the residual series of this OLS regression as our sentiment measure $(S)$. For France, Germany, and the Netherlands, the GDP and $S$ are at the country level, whereas $D$ and $R$ reflect the whole Euro area. For Australia, the U.K., and the U.S., all the aforementioned series are national ones.
As a novelty compared with earlier research on the topic, we additionally include in the analysis a variable that aims to capture global liquidity $(L)$. Following the definition by the Bank of International Settlements (BIS), the term 'global liquidity' refers here to the ease of financing in global financial markets. Given that we are interested in the influence of market and funding liquidity on the asset returns, our measure of global liquidity is the total credit from banks to the nonbank sector globally (this liquidity indicator is provided by BIS; for the global liquidity definitions, see Domanski, Fender, and McGuire 2011). The liquidity measure as well as data on all the other economic fundamentals are downloaded from Macrobond. Table A1 in the appendix summarizes the variables we use.

As a preliminary check, we report panel unit root tests to examine the stationarity of each variable. Since the data include notable cross-sectional correlation, we report the cross-sectional augmented IPS (CIPS) panel unit root test (Pesaran 2007). The CIPS test is based on ADF regressions that are augmented with cross-sectional averages of the variables (i.e., CADF regressions) and is thereby not biased by cross-sectional dependence in the data. The test also allows for heterogeneity across countries. The results reported in Table 1 indicate that, as expected based on earlier empirical evidence, the variables should be treated as nonstationary in levels. For all the differenced variables, the test statistics indicate stationarity.

\section{Empirical analysis}

\section{Return and volatility comparisons}

Table 2 reports the average returns, standard deviation of returns, and F-tests of equality of means and standard deviations for listed and direct real estate investments. Results are reported at the panel level and by country. Most important for the purposes of this study is to consider the panel level results, reported at the top of Table 2: the panel level results in particular correspond to our 'broad view' in terms of considering, in practice, a portfolio with equal weights for each of the six countries.

Panel results indicate that the returns on direct and listed investments are not statistically different 
Table 1. CIPS unit root test statistics.

\begin{tabular}{lcc}
\hline Variable & Level & Difference \\
\hline REIT & -1.115 & $-3.786^{* *}$ \\
Direct real estate & -2.240 & $-3.133^{* *}$ \\
GDP & -1.277 & $-1.729^{*}$ \\
Interest rate & -1.726 & $-2.673^{* *}$ \\
Risk premium & -2.146 & $-5.939^{* *}$ \\
Sentiment & -2.274 & $-3.569^{* *}$ \\
Global liquidity & $-1.374^{\mathrm{a}}$ & $-2.086^{* a}$ \\
\hline * $^{*}$ and ${ }^{* *}$ denote statistical significance at the $5 \%$ and 1\% level, respectively. \\
The null hypothesis is that of non-stationarity. The CIPS test statistics are \\
based on country-specific CADF regressions. The number of lags in the \\
CADF regressions is allowed to vary across countries. For each country, the \\
lag length is based on the general-to-specific method, using a threshold \\
significance level of 5\% and a maximum lag length of four. The CADF \\
regressions for levels include a country-specific intercept, and those for \\
differenced variables do not include any deterministic variables. ${ }^{\text {a }}$ Since the \\
global liquidity variable is the same for all the countries, the DF-GLS unit \\
root test is applied to the global liquidity series.
\end{tabular}

sector composition - is excluded from the panel. At the broad, i.e., panel, level the mean return point estimates of unlevered listed and direct investments are of similar magnitude in terms of economic significance as well. When Germany is excluded from the analysis, the mean returns are particularly close to each other $(7.3 \%$ vs. $7.2 \%)$. Hence, the statistics reported in Table 2 indicate that direct and listed real estate investments provide similar mean return and volatility characteristics at the broad level (when leverage is controlled for). This is in line with the fact that both are based on the same underlying assets. It is also consistent

Table 2. Means, standard deviations and F-tests by country and overall (with and without Germany).

\begin{tabular}{|c|c|c|c|c|c|c|c|c|}
\hline & \multicolumn{4}{|c|}{ With Germany } & \multicolumn{4}{|c|}{ Without Germany } \\
\hline & $\begin{array}{c}\text { Average } \\
(\%)\end{array}$ & $\begin{array}{c}\text { Standard } \\
\text { Deviation (\%) }\end{array}$ & $\begin{array}{c}\text { F-test } \\
\text { ( } p \text {-value) of } \\
\text { Equal Means }\end{array}$ & $\begin{array}{c}\text { F-test } \\
\text { ( } p \text {-value) of } \\
\text { Equal Variances }\end{array}$ & $\begin{array}{c}\text { Average } \\
(\%)\end{array}$ & $\begin{array}{c}\text { Standard } \\
\text { Deviation (\%) }\end{array}$ & $\begin{array}{c}\text { F-test ( } p \text {-value) of } \\
\text { Equal Means }\end{array}$ & $\begin{array}{c}\text { F-test } \\
\text { (p-value) of } \\
\text { Equal Variances }\end{array}$ \\
\hline Panel Overall & & & & & & & & \\
\hline Direct & 6.65 & 11.91 & & & 7.18 & 12.91 & & \\
\hline Listed Lev. & 8.09 & 23.65 & 0.565 & $0.000^{* * *}$ & 8.42 & 21.71 & 0.635 & $0.000^{* * *}$ \\
\hline $\begin{array}{l}\text { Listed Unlev. } \\
\text { Australia }\end{array}$ & 7.25 & 10.50 & 0.689 & 0.181 & 7.30 & 10.74 & 0.945 & $0.077^{*}$ \\
\hline Direct & 8.94 & 9.70 & & & & & & \\
\hline Listed Lev. & 5.88 & 23.52 & 0.603 & $0.001^{* * *}$ & & & & \\
\hline $\begin{array}{l}\text { Listed Unlev. } \\
\text { France }\end{array}$ & 6.73 & 11.58 & 0.528 & 0.461 & & & & \\
\hline Direct & 7.93 & 9.95 & & & & & & \\
\hline Listed Lev. & 12.51 & 21.24 & 0.401 & $0.002^{* * *}$ & & & & \\
\hline $\begin{array}{l}\text { Listed Unlev. } \\
\text { Germany }\end{array}$ & 8.46 & 10.84 & 0.877 & 0.719 & & & & \\
\hline Direct & 4.02 & 3.46 & & & & & & \\
\hline Listed Lev. & 6.42 & 22.71 & 0.751 & $0.000^{* * *}$ & & & & \\
\hline $\begin{array}{l}\text { Listed Unlev. } \\
\text { Netherlands }\end{array}$ & 7.01 & 9.42 & 0.202 & $0.000^{* * *}$ & & & & \\
\hline Direct & 6.56 & 6.31 & & & & & & \\
\hline Listed Lev. & 7.45 & 19.51 & 0.852 & $0.000^{* * *}$ & & & & \\
\hline $\begin{array}{l}\text { Listed Unlev. } \\
\text { U.K. }\end{array}$ & 6.39 & 10.62 & 0.953 & $0.033^{* *}$ & & & & \\
\hline Direct & 6.07 & 18.94 & & & & & & \\
\hline Listed Lev. & 6.47 & 25.44 & 0.957 & 0.221 & & & & \\
\hline $\begin{array}{l}\text { Listed Unlev. } \\
\text { U.S. }\end{array}$ & 6.97 & 12.65 & 0.866 & $0.095^{*}$ & & & & \\
\hline Direct & 6.40 & 16.63 & & & & & & \\
\hline Listed Lev. & 9.79 & 19.97 & 0.574 & 0.426 & & & & \\
\hline Listed Unlev. & 7.96 & 8.68 & 0.720 & $0.009 * * *$ & & & & \\
\hline
\end{tabular}

$*{ }^{* *}$ and ${ }^{* * *}$ denote statistical significance at the $10 \%, 5 \%$ and $1 \%$ level, respectively.

from one another regardless of whether listed returns are levered or unlevered. In contrast, the variance of levered listed returns is much greater than that of direct real estate. This difference in variance disappears once listed returns are unlevered. The conclusions remain similar when Germany - which differs from the other countries in the analysis due to the greater discrepancy between EPRA/NAREIT and MSCI in the property with previous empirical evidence by Pagliari, Scherer, and Monopoli (2005) and Hoesli and Oikarinen (2016).

Returns of direct and listed real estate are not significantly different in any of the countries, and the return point estimates of unlevered REITs are relatively close to those of direct real estate. The lack of any significant differences in average returns in individual countries may be partly due 


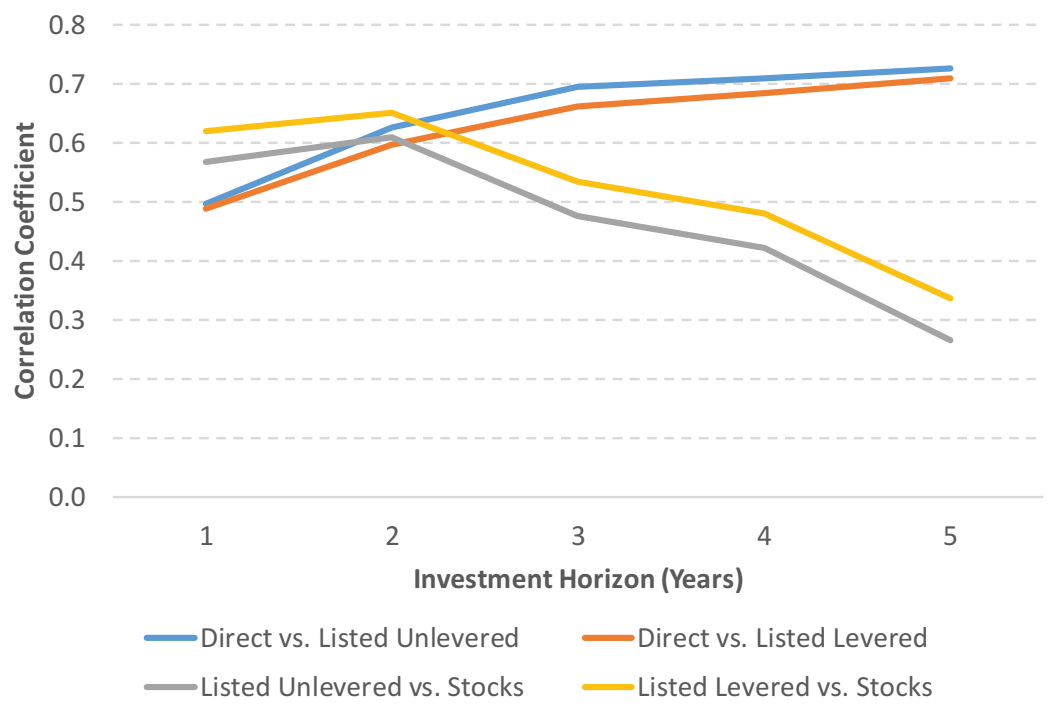

Figure 2. Correlations between listed real estate and direct real estate and stocks.

to the small number of observations and the complications with the F-test discussed in section 2, though. In Germany and Australia, the difference between the average unlevered REIT and MSCI returns is greater than in the other countries. Unlevered REIT returns were more volatile than MSCI returns only in Germany and the Netherlands during the sample period, and the direct market appears to be very volatile in both the U.S. and the U.K. Germany stands out: the direct market has a very low volatility and unlevered listed returns are much higher than returns on direct investments. ${ }^{1}$

Figure 2 shows the REIT and direct real estate return correlations, and for comparison also the correlations between REITs and the overall stock market, at the panel level depending on the assumed investment horizon from one to five years. $^{2}$ Beyond the two-year horizon the correlation between listed and direct real estate continues to increase while that between listed real estate and stocks declines. Unlevering listed returns does not alter any of those conclusions. ${ }^{3}$ The increasing correlation between listed and direct real estate with the time horizon is in line with the results of Hoesli and Oikarinen (2016) using sector data for the U.S.

While the small number of observations does not allow for similar country-level correlation curves as presented in Figure 2, the panel level analysis in any case is the important one for the broad view of comparing the listed and direct markets. Nevertheless, country-level results also imply that the correlation between listed and direct real estate increases with the time horizon extending from one to two years (Table A2 in the appendix).

In Germany, the correlation between listed and direct real estate is very low. This is presumably due to different property types being considered in each index - while the residential sector dominates the German REIT index, commercial real estate has a major weight in the direct market index. This implies that if the property type mixes are 'too' far apart, then the broad REIT and direct market portfolios/indexes do not work as substitutes, even if they do so at the broad international, multicountry level. The implication is in line with several articles showing notable differences across

\footnotetext{
${ }^{1}$ The desmoothing parameter of 0.5 implies that appraised values take one year to reflect market conditions. We also tested whether the volatility difference between $\mathrm{MSCl}$ and unlevered REITs in Germany becomes insignificant if a desmoothing parameter of 0.67 is applied (this parameter assumes that it takes two years for the appraisals to reflect market conditions): the direct market standard deviation increases from $3.64 \%$ to $4.97 \%$, but the volatility difference between the assets remains significant.

${ }^{2}$ The correlations over horizons longer than one year are computed using overlapping observation windows to keep the number of observations greater and thus to be able to estimate the correlations more reliably. The stock returns are based on broad stock market total return indexes for each country: ASX (Australia), CAC40 (France), MDAX (Germany), AEX All Share (Netherlands), FTSE All Share (the U.K.), and S\&P 500 Composite (the U.S.).

${ }^{3}$ The variations in the correlation coefficients between one and five-year horizons are highly statistically significant for all the four presented return pairs. Also, at the longer horizons, the differences between REIT-direct and REIT-stock correlations are highly significant.
} 
Table 3. FMOLS results.

\begin{tabular}{|c|c|c|c|c|c|c|}
\hline \multicolumn{7}{|c|}{ Dependent variable: REIT } \\
\hline \multicolumn{7}{|c|}{ Right-hand side variable: $\mathrm{MSCl}$} \\
\hline \multicolumn{7}{|l|}{ Panel Results } \\
\hline & With Germany & & Without Germany & & & \\
\hline & Pooled FMOLS & Mean-Group FMOLS & Pooled FMOLS & Mean-Group FMOLS & & \\
\hline $\begin{array}{l}\text { Coefficient } \\
\text { (Standard Error) }\end{array}$ & $\begin{array}{l}1.123^{* * * *} \\
(0.065)\end{array}$ & $\begin{array}{l}1.261^{* * *} \\
(0.049)\end{array}$ & $\begin{array}{c}1.087^{* * * *} \\
(0.066)\end{array}$ & $\begin{array}{l}1.174^{* * *} \\
(0.046)\end{array}$ & & \\
\hline CIPS Test & $-1.809^{* *}$ & $-2.564^{* * *}$ & -1.281 & $-2.247^{* * *}$ & & \\
\hline Wald Test & $0.062^{*}$ & $0.000^{* * *}$ & 0.187 & $0.000 * * *$ & & \\
\hline Homogeneity Test & & $0.000^{* * *}$ & & $0.000^{* * *}$ & & \\
\hline \multicolumn{7}{|c|}{ Individual Country Coefficients } \\
\hline & Australia & France & Germany & Netherl. & U.K. & U.S. \\
\hline Coefficient & $0.716^{* * *}$ & $1.231^{* * *}$ & $1.701^{* * *}$ & $1.320^{* * *}$ & $1.267^{* * *}$ & $1.333^{* * *}$ \\
\hline (Standard Error) & $(0.063)$ & $(0.057)$ & (0.194) & (0.109) & $(0.133)$ & $(0.151)$ \\
\hline Wald Test & $0.000^{* * *}$ & $0.001^{* * *}$ & $0.002^{* * *}$ & $0.010^{* *}$ & $0.061^{*}$ & $0.042^{* *}$ \\
\hline
\end{tabular}

property sectors in terms of mean returns, return volatilities, and return dynamics (Hoesli and Oikarinen 2012; Hoesli, Oikarinen, and Serrano 2015; Ling and Naranjo 2015).

\section{Regression and cointegration analysis}

Table 3 contains the FMOLS regression results. In the FMOLS and SVAR models, we use only unlevered REIT data. Based on the pooled FMOLS results, the long-term similarity of listed and direct returns is a borderline case in terms of statistical significance: the point estimate on MSCI is 1.12, and the one-to-one relationship between the indexes could be rejected at the $6.2 \%$ level by the Wald test. The MG-FMOLS estimate is slightly greater (1.26) and differs significantly from one implying that over the long run unlevered REIT returns are overall slightly greater than the broad direct market returns. These models also are cointegrated based on the CIPS test, indicating that the estimated relationship represents a tight long-term relationship between the indexes towards which the markets tend to move. Figure A1 in the appendix shows that - despite some notable deviations in the short term, especially around the GFC period the REIT (unlevered) total return indexes follow the estimated relations closely during the sample period. Note that the MG-FMOLS model is preferred over PFMOLS, since the Pedroni (2007) homogeneity test indicates that there is significant cross-sectional variation in the coefficient estimates - hence the model fits presented in Figure
A1 are based on the MG-FMOLS country-specific estimates.

Given the peculiarity of the German case, we repeat the estimations without Germany. In these estimations, the point estimates are somewhat closer to one, and the hypothesis of the coefficient on MSCI being equal to one is now clearly accepted in the PFMOLS model, which is not stationary though. Based on the stationary MG-FMOLS model, the hypothesis of a one-to-one long-run relationship can be rejected without Germany as well. Therefore, the panel FMOLS models overall present evidence of unlevered REIT returns being slightly greater than the broad direct market returns: the point estimate of 1.26 suggests that a $1 \%$ direct market return, on average, corresponds to a $1.26 \%$ unlevered REIT return.

Despite the heterogeneity across countries as exhibited by the homogeneity test statistics and the individual country point estimates, the key insights of the regression models are: (1) an investor can track the longer-run return developments of a broad direct market investment portfolio that includes real estate from the six countries by investing in broad REIT indexes for the same countries, and (2) the expected return on a broad REIT portfolio for the six countries is slightly higher than that on the broad direct market portfolio. This is in contrast with the F-test results according to which the equality of expected returns for unlevered listed and direct real estate cannot be rejected. Given the complications with the simple F-test discussed in section 2 , the regression results are the preferred 
ones. The higher expected return on REITs implies that investors set slightly greater risk premia for REITs, possibly due to the much greater shorthorizon correlation between REIT and stock returns than that between direct real estate and stock returns.

The finding that unlevered listed and direct real estate total return indexes are cointegrated is in line with several previous studies for individual countries in which property type has been controlled for (Boudry et al. 2012; Hoesli and Oikarinen 2012; Yunus, Hansz, and Kennedy 2012; Hoesli, Oikarinen, and Serrano 2015; Hoesli and Oikarinen 2016, who also test for the one-to-one relationship between the return indexes). These analyses generally suggest that only direct real estate prices adjust towards the long-run relation. An exception is the study by Boudry et al. (2012) which reports significant adjustment of both securitized and direct markets.

\section{Panel SVAR analysis}

Given that the return indexes are cointegrated, the estimated SVAR model includes an errorcorrection mechanism: the one period lagged deviation of REITs (based on the MG-FMOLS parameter estimates) from the long-term relation is included as an additional variable in the equations for real estate returns. In line with most previous evidence, only direct market returns adjust statistically significantly towards the long-term equilibrium relation, the estimated annual adjustment speed being 37\%. Nevertheless, we do not restrict REITs to be weakly exogenous, i.e., we allow for REITs too to adjust towards the longterm relation (the adjustment speed is $3.3 \%$ ). This does not affect the SVAR results.

In addition to the real estate returns and the error-correction term, the SVAR model includes five fundamentals: $G D P, D, R, S$, and $L$, of which GDP and global liquidity are in the natural log form. The fundamentals are included in the model in differences, as they are non-stationary in levels but stationary in the first difference. The model includes one lag based on the Schwartz
Bayesian Criterion. ${ }^{4}$ Hence, the effective sample size in the SVAR estimation is 108 observations.

We estimate the SVAR model to investigate and compare the reaction patterns of broad REIT market returns and broad direct real estate market returns to various economic shocks. Hence, the examination of impulse response functions (IRFs) is of major interest here. We identify the shocks from the system by imposing 15 short-term restrictions in the model. Hence, the model is just-identified. The restrictions are based on theoretical considerations and previous empirical observations regarding the reactions of the variables to various shocks. It is assumed that GDP is only affected contemporaneously by its own shocks, but shocks in GDP influence all the other variables simultaneously. This is a common assumption in SVAR models, as the real economy is usually assumed and has been shown to respond sluggishly to shocks in other variables, and because changes in income (GDP) are expected to affect rapidly the other variables.

The sentiment, too, is assumed to be sluggish to react: $S$ is allowed to react contemporaneously only to shocks in GDP, since sentiment tends to be considerably more rigid to adjust in the short term than financial variables. As listed securities should react immediately to shocks in the fundamentals, we do not impose any restrictions on the short-term REIT reactions. However, given the substantial frictions in the direct real estate market and the lead-lag relations between REIT and direct market returns observed in the literature (Hoesli and Oikarinen 2012; Yunus, Hansz, and Kennedy 2012; Hoesli, Oikarinen, and Serrano 2015), the direct market is restricted to react to REIT shocks only with lag. Although the empirical literature suggests that the direct market absorbs the information revealed by the listed market sluggishly, we also investigated whether the IRFs are notably different if the direct market is allowed to concurrently react to REIT shocks. While there are no more than negligible differences in the other IRFs, the assumption affects the short-term reaction of direct real estate to a REIT shock hence we also show this IRF.

\footnotetext{
${ }^{4}$ This criterion tends to be more accurate than alternative ones for the kind of sample size that we have (Ivanov and Kilian 2005). One lag appears to be sufficient to capture the model dynamics, as the null hypothesis of no autocorrelation in model residuals is not rejected (the p-value being 0.15 ) in the Lagrange Multiplier test with lag length two. The estimated SVAR also meets the stability condition, as all the eigenvalues lie inside the unit circle.
} 
To distinguish the shocks stemming from financial market variables from each other, we impose restrictions to the short-term reactions of $D, L$, and $R$. For one, we wish to be able to make a distinction between credit/liquidity supply shocks ('global liquidity shocks') and credit demand shocks. In the empirical literature, it has proven to be extremely hard to separate between credit supply and credit demand shocks in SVAR analyses (e.g., Peek, Rosengren, and Tootell 2003; Uhlig 2005). Second, the aim is to identify a risk premium shock that can be distinguished from the credit shocks. For these purposes, we allow $R$ to simultaneously react to the other two financial market shocks, while $L$ does not respond immediately to shocks originating from $R$, and $D$ is restricted not to react immediately to shocks taking place in $L$ or $R$. Furthermore, $D, L$, and $R$ are restricted not to react concurrently to real estate market shocks, which also helps in distinguishing real estate shocks from shocks that originate from the economic fundamentals included in the analysis. As explained below, the imposed restrictions yield shocks that can be interpreted as liquidity supply, credit demand, and risk premium shocks as wished. ${ }^{5}$

Figures 3 and 4 show the reactions (i.e., the IRFs) of unlevered REIT returns and direct market returns to the seven shocks up to eight years from the shock. ${ }^{6}$ The accumulated IRFs are shown to illustrate the overall longer-term reactions. Figures 3 and 4 are aimed especially at comparing the responses of listed vs. direct real estate, and including confidence bands for IRFs would make these graphs difficult to read. Hence, separate pictures that include the confidence bands for each of the reported IRFs are included in the appendix (Figures A2 and A3).

The first shock is interpreted as a technology shock in the economy, as it induces a permanent increase in GDP and, in line with, e.g., Gali (1999) and Ireland (2004), increases in the interest rate. The second shock is a positive sentiment innovation that leads to asset price increases and to GDP growth with lag. The third shock can be interpreted as an unexpected increase in the risk premium, leading to lower GDP, asset prices, and global liquidity. The fourth and fifth shocks, in turn, can be distinguished as a positive global liquidity (credit supply) shock and positive credit demand shock. A positive credit supply shock is one that increases credit with no increase, or even a decrease as in our case, in the interest rate. In contrast, a positive credit demand shock leads to increases in both credit and the interest rate. Finally, the last two shocks are those originating from the direct real estate market (sixth shock) and the REIT market (seventh shock).

Figure 3 includes the reactions of listed and direct real estate to the five first shocks, i.e., to shocks in the economic fundamentals. The most important observation is that the reactions to the different shocks generally are similar. This is particularly prominent over longer horizons, implying that REITs and direct real estate provide similar exposure to various economic risk factors over investment horizons that are typical for real estate investors, and is in line with the results reported above in that a broad REIT index can be used to track the broad direct market performance reasonably well. The estimated IRFs are also in line with those presented in Hoesli and Oikarinen (2012). All the responses are significant, at least in the short run, except for those on a technology shock.

The important difference between this analysis and that of Hoesli and Oikarinen (2012) is that sectoral-mix is not controlled for in the current analysis. Thus, our SVAR results too include the novel implication that an investor does not necessarily need to worry about sectoral composition when aiming to track the broad direct investment market performance by REITs, as a broad REIT index appears to do a good job in giving such an exposure, at least if an investor is aiming to diversify across the six countries included in this analysis.

Other novelties in this analysis compared with that in Hoesli and Oikarinen (2012) are the use of a panel of multiple countries, the examination of

\footnotetext{
${ }^{5}$ The identification of the IRFs is based on a short-term restriction structure similar to the Cholesky decomposition. Since the ordering of the variables, i.e., the imposed restrictions, is based on economic considerations and reasonable economic interpretation can be given for each of the shocks, the model can be seen as a SVAR.

${ }^{6}$ In the SVAR analysis too, the results basically are based on assuming similar portfolio weights for each of the countries. We checked the IRFs with some alternative identifying restrictions as well. While the conclusions regarding the similarity of mid- to long-run real estate return responses and faster short-term reaction of REITs remain valid, the interpretation of fundamental shocks are much less clear with these alternative structures.
} 

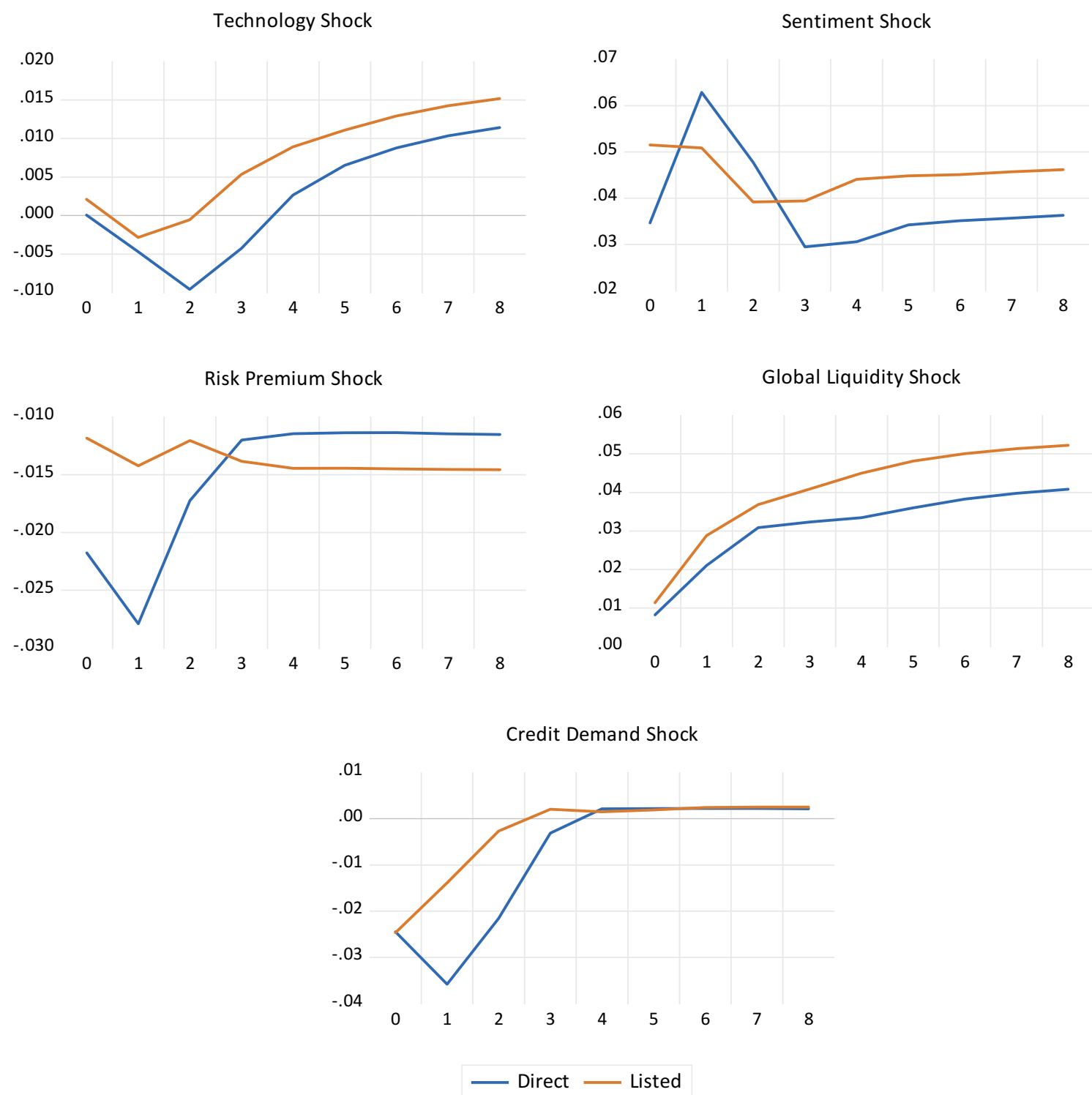

Figure 3. Accumulated impulse responses of listed and direct real estate to one standard deviation shocks in economic fundamentals.

the shocks based on a structural VAR, and the investigation of the influences of a global liquidity shock. As expected, real estate returns are positively influenced by the sentiment and global liquidity shocks: while higher sentiment predicts greater growth in demand for real estate space, better liquidity (greater availability of credit) is expected to increase asset demand. Also in line with prior expectations, a risk premium shock has a negative impact on real estate values. The influence of the technology shock on real estate is negative initially due to an increase in the interest rate (discount factor effect), but turns positive over the longer run. Because of the increased interest rate, the short-term effect of a credit demand shock on real estate returns is negative, but this influence eventually vanishes.

Figure 4 presents the reaction of real estate returns to shocks in each other. These shocks can originate from multiple sources (other than the fundamentals included in the model) that can influence real estate returns including, e.g., institutional changes in real estate markets. The specific sources of these shocks remain unknown, but we name these real estate shocks since only real estate returns, and not the key fundamentals included in the model, react to these shocks concurrently. While the listed market reacts rapidly to direct real estate market shocks, the 
REIT Market Shock

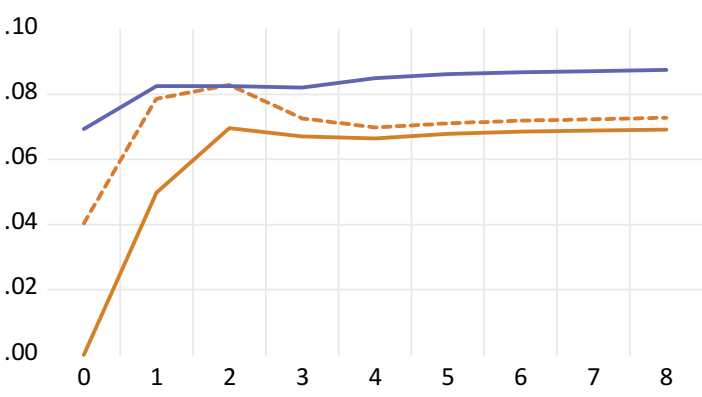

Direct Market Shock

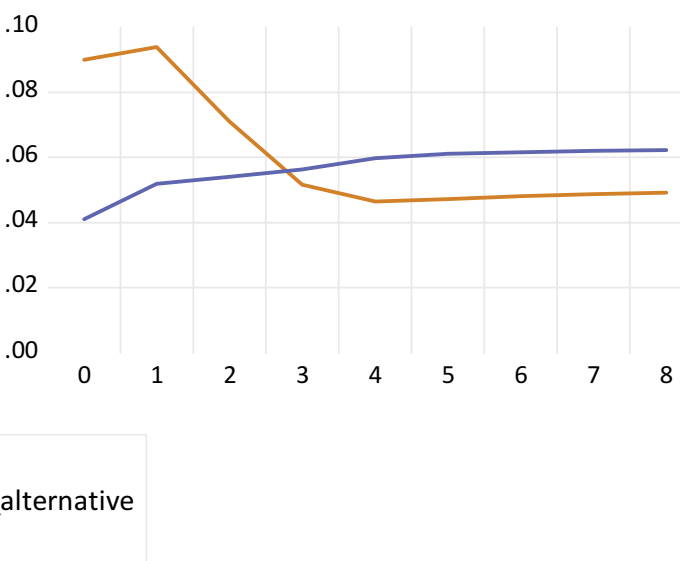

Figure 4. Accumulated impulse responses of listed and direct real estate to one standard deviation shocks in each other.

response of the direct market to REIT shocks is highly sluggish. This is in line with earlier literature. Obviously, the observed direct market reaction is more rapid if direct real estate is allowed to immediately react to REIT related shocks (shown by the dashed curve), but even in that case the first year reaction is only about half of the eventual overall influence of the shock. Anyhow, the IRFs indicate that over a horizon of several years the two types of real estate assets react to real estate-related shocks in a similar manner.

Interestingly, the real estate-related shocks have a positive effect on global liquidity. This interaction between global liquidity (i.e., global availability of credit) and real estate values is in line with the financial accelerator mechanism (Bernanke, Gertler, and Gilchrist 1999; Kiyotaki and Moore 1997) that can create self-reinforcing cycles between real estate values and credit supply and thereby strengthen or even cause macroeconomic cycles. ${ }^{7}$ This can also be seen in the listed and direct real estate reactions to the global liquidity shock: they keep increasing still many years after the initial shock.

\section{Conclusions}

This paper makes use of data for six prominent markets, accounting for over $70 \%$ of the free float of REIT market capitalization in developed countries, and modern panel econometrics to shed more light on the relationship between listed and direct real estate investments. We adopt a broad approach in that we consider a panel of several countries and whether investing in a REIT index rather than a direct real estate index - without controlling for compositional effects related to property types and locations - yields similar return and risk characteristics. Our results suggest that this generally is the case: once leverage of REITs and management costs of direct real estate have been controlled for, the returns and return volatilities of the two types of real estate exposure are of similar magnitude at the panel level, although the cointegrating group-mean FMOLS regression indicates that the long-term return on REITs is slightly greater than that of the direct real estate market. Moreover, the correlation between listed and direct real estate increases with the time horizon, while the correlation between listed real estate and stocks declines.

Based on a panel SVAR model, the returns of the two types of real estate assets also react similarly to various economic shocks. This indicates that the broad listed and direct real estate return indexes provide similar exposure to economic risk factors. While we observe positive global liquidity shocks to

\footnotetext{
${ }^{7}$ It is reasonable to assume that the real estate market reactions are mostly due to increases in asset values: values are expected to increase due to the impact of greater credit availability on capitalization rates [a discussion and empirical evidence are provided by Chervachidze and Wheaton (2013); see Kiyotaki and Moore (1997) for a theoretical discussion]. The influence of such shocks on rents is less clear, as based on the four-quadrant model of the real estate market (DiPasquale and Wheaton 1992) the impact on rents could even be negative. In any case, any changes in rents directly affect values as well.
} 
increase both listed and direct real estate values, we also find positive real estate market shocks to increase the liquidity. These observations are in line with the well-known financial accelerator mechanism.

Given the aim, data, and methods in this study, the main conclusions concern an investor who aims to track the performance of a broad portfolio of direct real estate investments in a number of prominent markets by investing in listed real estate. For such an investor, the key implication is that one does not necessarily need to put effort in trying to track the property type mix and within-country geographic composition of the direct investment market, as even the broad REIT indexes appear to do reasonably well in tracking the broad direct market performance over a mid- to long-term investment horizon.

While this appears to be the case for a portfolio that is well diversified across major countries, it does not apply for all individual countries: in single countries, the discrepancy in the property type compositions of REITs compared with the direct market (as proxied by the MSCI index) can be large enough to yield notable differences in the performance between the listed and direct markets (Germany is an example). Moreover, the implication applies if the aim is to track a direct portfolio that would include similar leverage to that of REITs. If the aim is to track the unlevered direct portfolio performance, an investor would have to use other capital market instruments to remove the effect of leverage in REITs.

\section{Acknowledgments}

We thank the European Public Real Estate Association (EPRA) for providing REIT market data, and an anonymous referee for helpful comments. The paper also benefited from comments received at the conferences of the American Real Estate Society (ARES) in April 2019 in Phoenix (USA), the European Real Estate Society (ERES) in July 2019 in Cergy-Pontoise (France), and EPRA in September 2019 in Madrid (Spain).

\section{Disclosure statement}

No potential conflict of interest was reported by the authors.

\section{Funding}

This work was supported by the European Public Real Estate Association.

\section{References}

Andonov, A., P. Eichholtz, and N. Kok. 2015. "Intermediated Investment Management in Private Markets: Evidence from Pension Fund Investments in Real Estate." Journal of Financial Markets 22: 73-103. doi:10.1016/j.finmar.2014.11.002.

Arellano, M., and O. Bover. 1995. "Another Look at the Instrumental Variable Estimation of Error-Components Models." Journal of Econometrics 68 (1): 29-51. doi:10.1016/0304-4076(94)01642-D.

Bernanke, B., M. Gertler, and S. Gilchrist. 1999. "The Financial Accelerator in a Quantitative Business Cycle Framework." In Handbook of Macroeconomics, edited by J. Taylor and M. Woodford, 1341-1393. Amsterdam: North-Holland.

Boudry, W. I., N. E. Coulson, J. G. Kallberg, and C. H. Liu. 2012. "On the Hybrid Nature of REITs." Journal of Real Estate Finance and Economics 44 (1/2): 230-249. doi:10.1007/s11146-011-9339-7.

Chervachidze, S., and W. C. Wheaton. 2013. "What Determined the Great Cap Rate Compression of 2000-2007, and the Dramatic Reversal during the 2008-2009 Financial Crisis?" Journal of Real Estate Finance and Economics 46 (2): 208-231. doi:10.1007/ s11146-011-9334-z.

Delfim, J.-C., and M. Hoesli. 2019. "Real Estate in Mixed-Asset Portfolios for Various Investment Horizons." Journal of Portfolio Management 45 (7): 141-158. doi:10.3905/jpm.2019.45.7.141.

DiPasquale, D., and W. C. Wheaton. 1992. "The Markets for Real Estate Assets and Space: A Conceptual Framework." Real Estate Economics 20 (1): 181-198. doi:10.1111/15406229.00579.

Domanski, D., I. Fender, and P. McGuire. 2011. "Assessing Global Liquidity.” BIS Quarterly Review 2011 (December): 57-71.

Gali, J. 1999. “Technology, Employment, and the Business Cycle: Do Technology Shocks Explain Aggregate Fluctuations?" American Economic Review 89 (1): 249-271. doi:10.1257/aer.89.1.249.

Geltner, D., N. G. Miller, J. Clayton, and P. Eichholtz. 2007. Commercial Real Estate Analysis and Investments. Mason, $\mathrm{OH}$ : Thomson South-Western.

Haran, M., P. Davis, M. McCord, T. Grissom, and G. Newell. 2013. "Equities or Real Estate? an International Evaluation of Listed Property Markets." Journal of European Real Estate Research 6 (2): 139-162. doi:10.1108/JERER-032013-0002.

Hoesli, M., J. Lekander, and W. Witkiewicz. 2004. "International Evidence on Real Estate as a Portfolio Diversifier." Journal of Real Estate Research 26 (2): 161-206. 
Hoesli, M., and E. Oikarinen. 2012. “Are REITs Real Estate: Evidence from International Sector Level Data." Journal of International Money and Finance 31 (7): 1823-1850. doi:10.1016/j.jimonfin.2012.05.017.

Hoesli, M., and E. Oikarinen. 2016. "Are Public and Private Asset Returns and Risks the Same? Evidence from Real Estate Data." Journal of Real Estate Portfolio Management 22 (2): 179-198. doi:10.1080/10835547.2016.12089990.

Hoesli, M., E. Oikarinen, and C. Serrano. 2015. "Do Public Real Estate Returns Really Lead Private Returns?” Journal of Portfolio Management 41 (6): 105-117. doi:10.3905/ jpm.2015.41.6.105.

Ireland, P. N. 2004. "Technology Shocks in the New Keynesian Model.” Review of Economics and Statistics 86 (4): 923-936. doi:10.1162/0034653043125158.

Ivanov, V., and L. Kilian. 2005. “A Practitioner's Guide to Lag Order Selection for VAR Impulse Response Analysis." Studies in Nonlinear Dynamics \& Econometrics 9 (1): Article 2. doi:10.2202/1558-3708.1219.

Kiyotaki, N., and J. Moore. 1997. “Credit Cycles.” Journal of Political Economy 105 (2): 211-248. doi:10.1086/262072.

Li, J., R. M. Mooradian, and S. X. Yang. 2009. "The Information Content of the NCREIF Index." Journal of Real Estate Research 31 (1): 93-116.

Lin, P.-T., and F. Fuerst. 2014. "The Integration of Direct Real Estate and Stock Markets in Asia." Applied Economics 46 (12): 1323-1334. doi:10.1080/00036846.2013.872763.

Ling, D. C., and A. Naranjo. 2015. "Returns and Information Transmission Dynamics in Public and Private Real Estate Markets." Real Estate Economics 43 (1): 163-208. doi:10.1111/1540-6229.12069.

Ling, D. C., A. Naranjo, and B. Scheick. 2014. "Investor Sentiment, Limits to Arbitrage and Private Market Returns." Real Estate Economics 42 (3): 531-577. doi:10.1111/1540-6229.12037.

Lizieri, C. 2013. "After the Fall: Real Estate in the Mixed Asset Portfolio in the Aftermath of the Global Financial Crisis." Journal of Portfolio Management 39 (5): 43-59.

MacKinnon, G. H., and A. Al Zaman. 2009. "Real Estate for the Long Term: The Effect of Return Predictability on Long-Horizon Allocations." Real Estate Economics 37 (1): 117-153. doi:10.1111/j.1540-6229.2009.00237.x.

Modigliani, F., and M. H. Miller. 1958. "The Cost of Capital, Corporation Finance and the Theory of Investment." American Economic Review 48 (3): 261-297.

Nickell, S. 1981. "Biases in Dynamic Models with Fixed Effects." Econometrica 49 (6): 1417-1426. doi:10.2307/ 1911408.

Oikarinen, E., M. Hoesli, and C. Serrano. 2011. "The Long-Run Dynamics between Direct and Securitized
Real Estate." Journal of Real Estate Research 33 (1): 73-103.

Pagliari, J. L., Jr. 2017. “Another Take on Real Estate’s Role in Mixed-Asset Portfolio Allocations.” Real Estate Economics 45 (1): 75-132. doi:10.1111/1540-6229.12138.

Pagliari, J. L., Jr, K. A. Scherer, and R. T. Monopoli. 2005. "Public versus Private Real Estate Equities: A More Refined, Long-Term Comparison." Real Estate Economics 33 (1): 147-187. doi:10.1111/j.1080-8620.2005.00115.x.

Pedroni, P. 2000. "Fully Modified OLS for Heterogeneous Cointegrated Panels." In Nonstationary Panels, Cointegration in Panels and Dynamic Panels, edited by B. H. Baltagi, 93-130. Amsterdam: Elsevier.

Pedroni, P. 2001. "Purchasing Power Parity Tests in Cointegrated Panels." Review of Economics and Statistics 83 (4): 727-731. doi:10.1162/003465301753237803.

Pedroni, P. 2007. "Social Capital, Barriers to Production and Capital Shares: Implications for the Importance of Parameter Heterogeneity from a Nonstationary Panel Approach." Journal of Applied Econometrics 22 (2): 429-451. doi:10.1002/jae.948.

Peek, J., E. S. Rosengren, and G. M. B. Tootell. 2003. "Identifying the Macroeconomic Effect of Loan Supply Shocks." Journal of Money, Credit and Banking 35 (6): 931-946. doi:10.1353/mcb.2003.0046.

Pesaran, M. H. 2007. “A Simple Panel Unit Root Test in the Presence of Cross-Section Dependence." Journal of Applied Econometrics 22 (2): 265-312. doi:10.1002/ jae.951.

Riddiough, T. J., M. Moriarty, and P. J. Yeatman. 2005. "Privately Versus Publicly Held Asset Investment Performance." Real Estate Economics 33 (1): 121-146. doi:10.1111/j.1080-8620.2005.00114.x.

Uhlig, H. 2005. "What are the Effects of Monetary Policy on Output? Results from an Agnostic Identification Procedure." Journal of Monetary Economics 52 (2): 381-419. doi:10.1016/j.jmoneco.2004.05.007.

Yang, E., S. H. Kim, M. H. Kim, and D. Ryu. 2018. "Macroeconomic Shocks and Stock Market Returns." Applied Economics 50 (7): 757-773. doi:10.1080/ 00036846.2017 .1340574$.

Yunus, N. 2018. "Transmission of Shocks across Global Real Estate and Equity Markets: An Examination of the 2007-2008 Housing Crisis." Applied Economics 50 (36): 3899-3922. doi:10.1080/00036846.2018.1430343.

Yunus, N., J. A. Hansz, and P. J. Kennedy. 2012. "Dynamic Interactions between Private and Public Real Estate Markets: Some International Evidence." Journal of Real Estate Finance and Economics 45 (4): 1021-1040. doi:10.1007/s11146-010-9297-5. 


\section{Appendix}

Table A1.

\begin{tabular}{|c|c|c|}
\hline $\begin{array}{l}\text { Variable } \\
\text { (abbreviation) }\end{array}$ & Definition & Source \\
\hline Listed real estate (REIT) & EPRA/NAREIT total return indexes & EPRA/NAREIT \\
\hline $\begin{array}{l}\text { Direct real estate } \\
\qquad(\mathrm{MSCl})\end{array}$ & $\mathrm{MSCl}$ total return indexes of institutional real estate holdings & $\mathrm{MSCl}$ \\
\hline REIT market leverage & Mean leverage level of constituent listed property companies over the time period & Bloomberg \\
\hline $\begin{array}{l}\text { Gross domestic } \\
\text { product }(G D P)\end{array}$ & GDP of each country & Macrobond \\
\hline $\begin{array}{l}\text { Default risk premium } \\
\text { (D) }\end{array}$ & $\begin{array}{l}\text { Spread between the low-grade corporate bond benchmark yield (BBB, Moody's) and the 10- } \\
\text { year government bond yield }\end{array}$ & Macrobond \\
\hline $\begin{array}{l}\text { Short-term interest } \\
\quad \text { rate }(R)\end{array}$ & Three-month interbank rate & Macrobond \\
\hline Consumer confidence & National consumer opinion survey values & Macrobond \\
\hline $\begin{array}{l}\text { Consumer sentiment } \\
(S)\end{array}$ & $\begin{array}{l}\text { Residual series of the OLS regression of consumer confidence on the economic fundamentals } \\
\qquad(G D P, D, R)\end{array}$ & Own computations \\
\hline Global liquidity $(L)$ & Total credit from banks to the non-bank sector globally & $\begin{array}{l}\text { Macrobond / Bank of International } \\
\text { Settlements }\end{array}$ \\
\hline
\end{tabular}


Australia
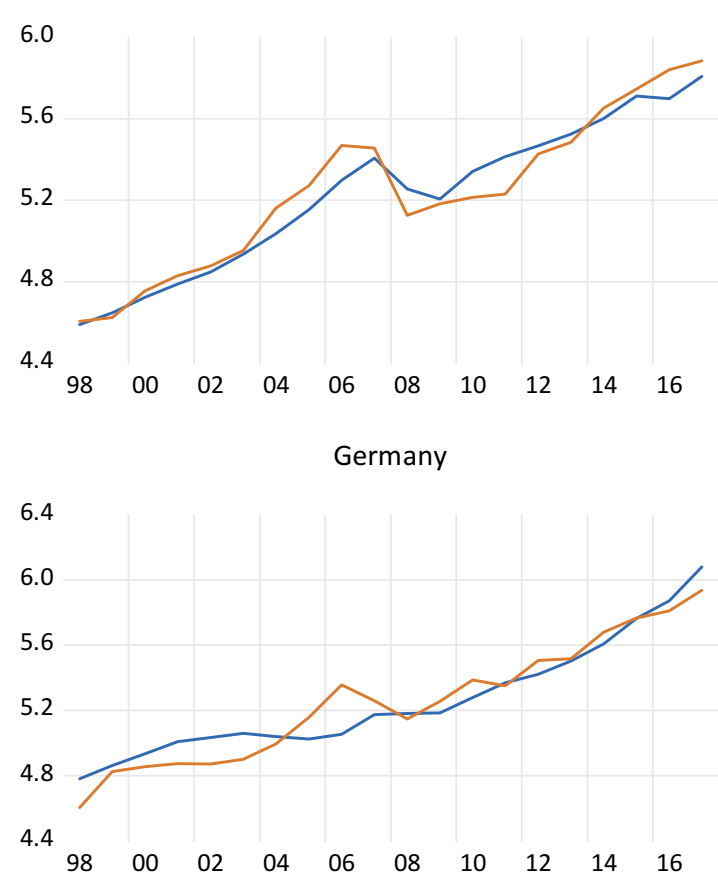

U.K.

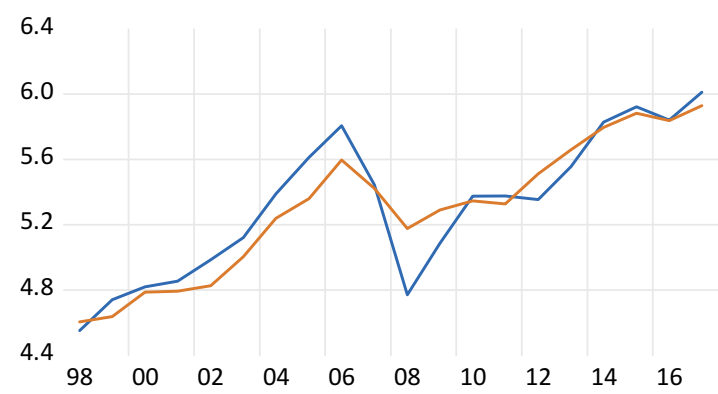

France
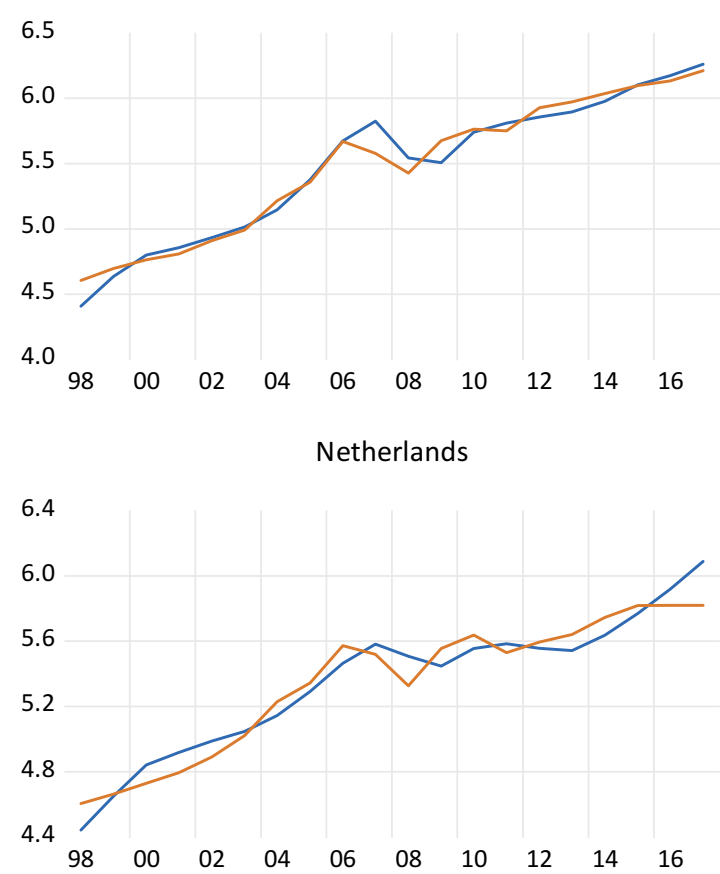

U.S.

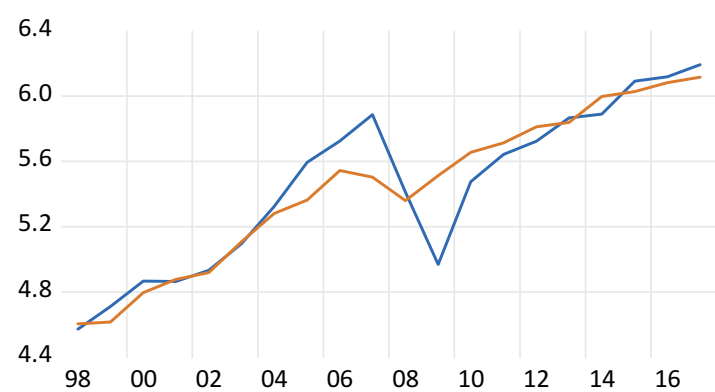
_ Fitted _ Actual

Figure A1. Actual unlevered listed indexes and MG-FMOLS fits (in natural logs). 


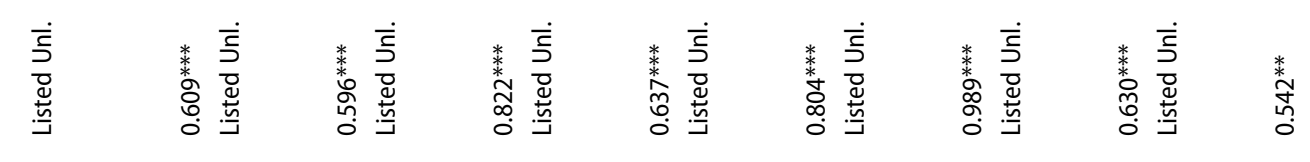

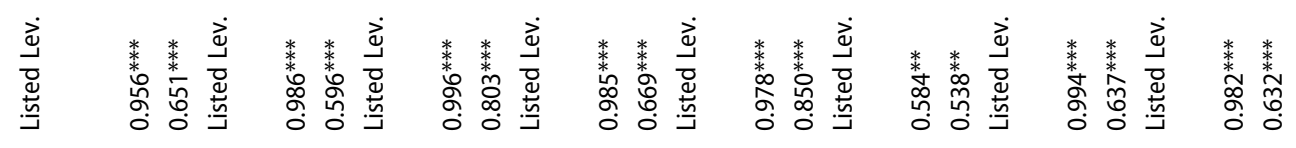

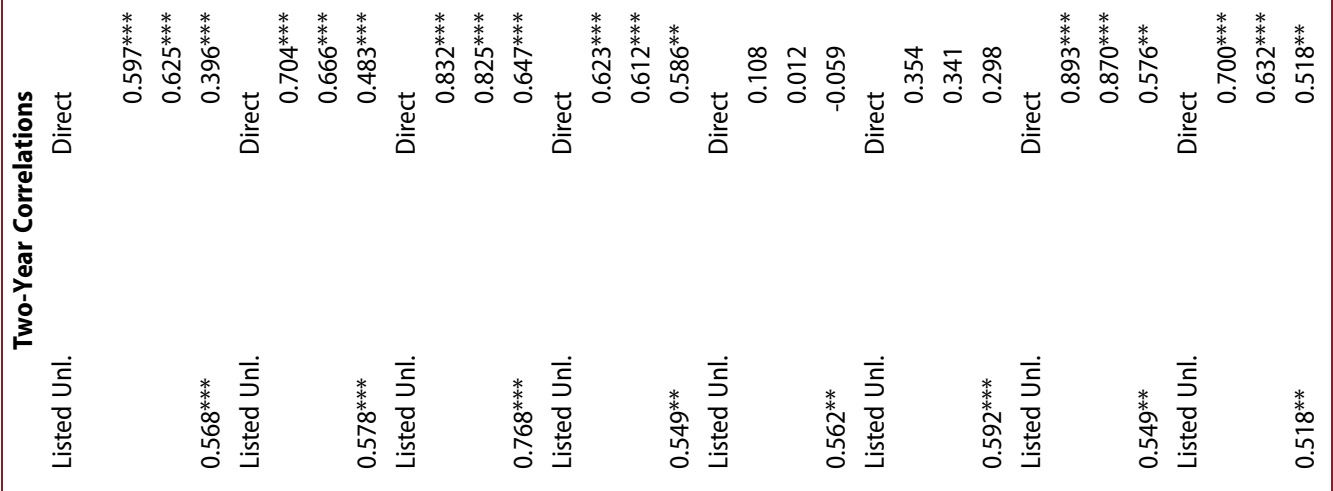

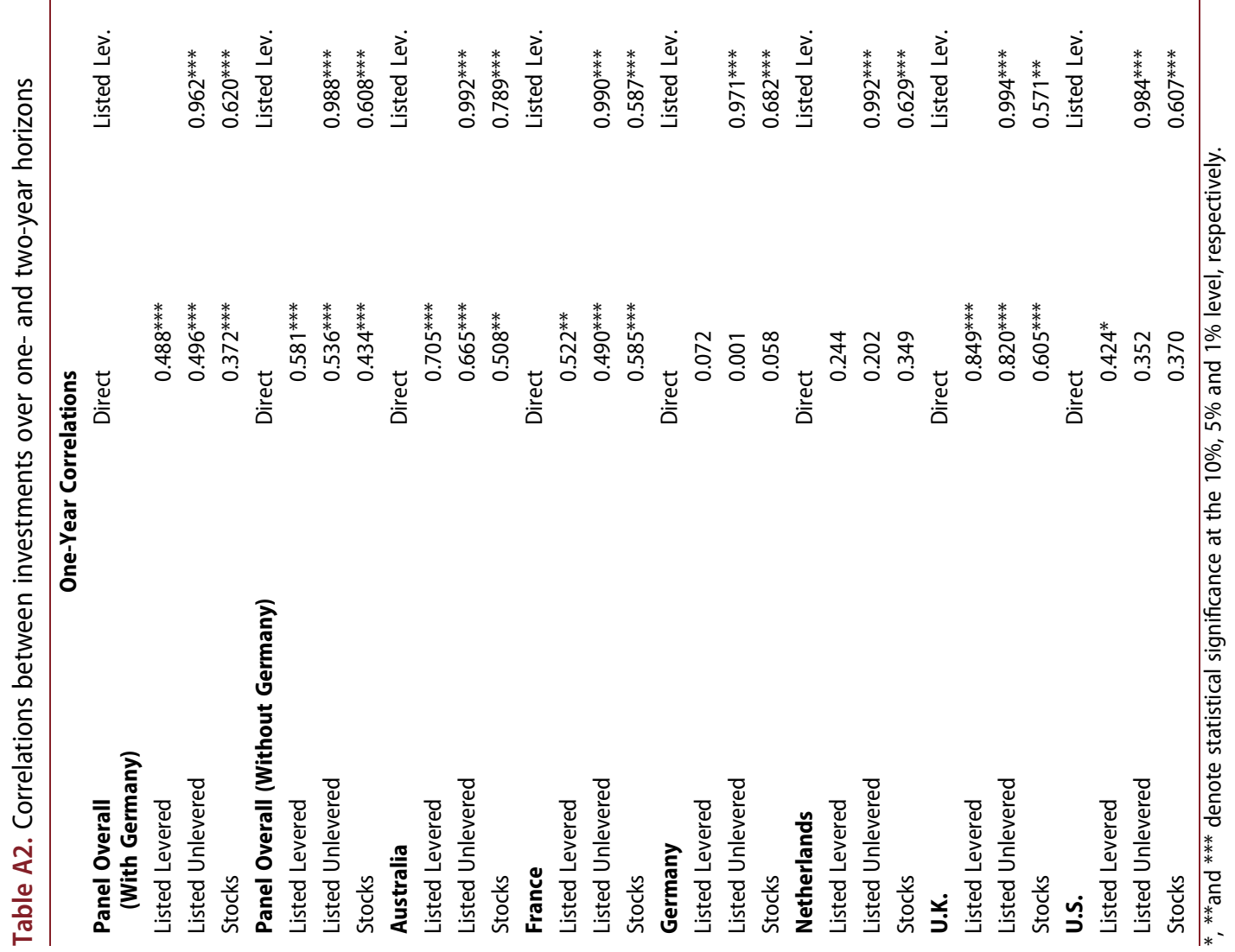


Technology Shock

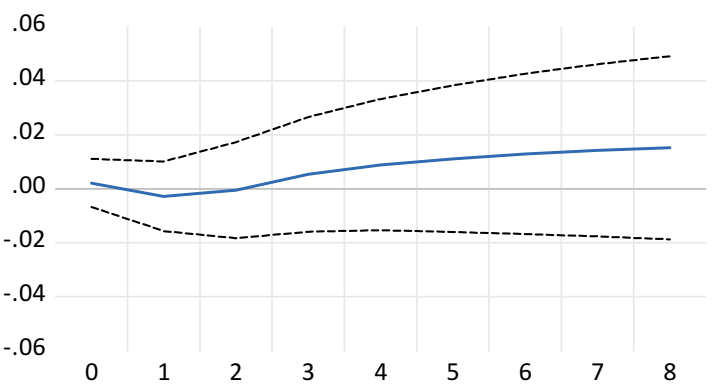

Risk Premium Shock

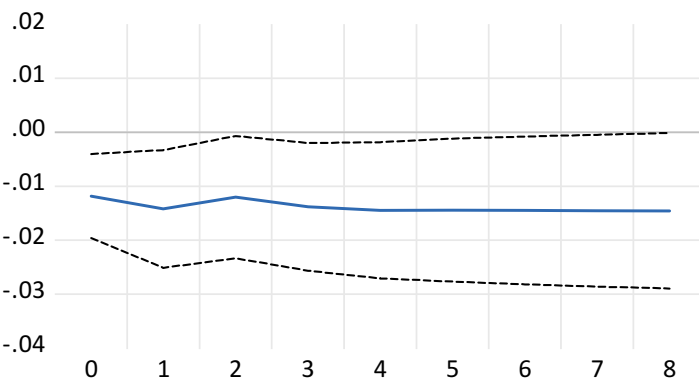

Direct Market Shock

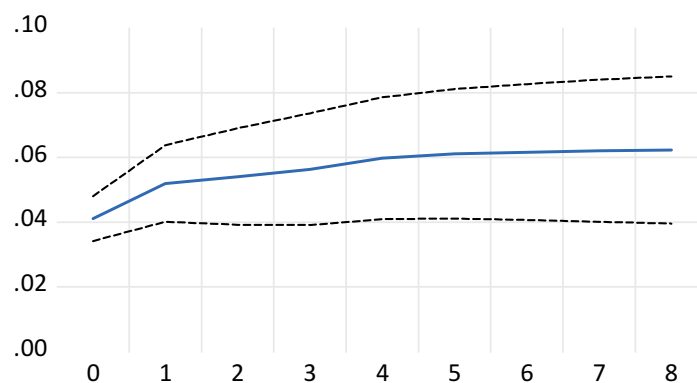

REIT Market Shock

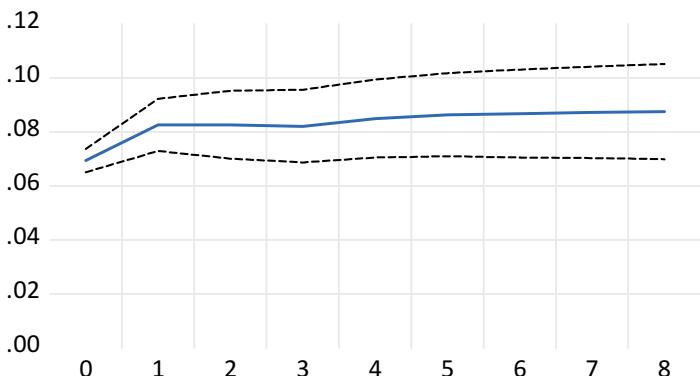

Figure A2. Accumulated impulse responses of listed real estate to one standard deviation shocks with $90 \%$ confidence bands based on Monte Carlo simulation with 500 draws.

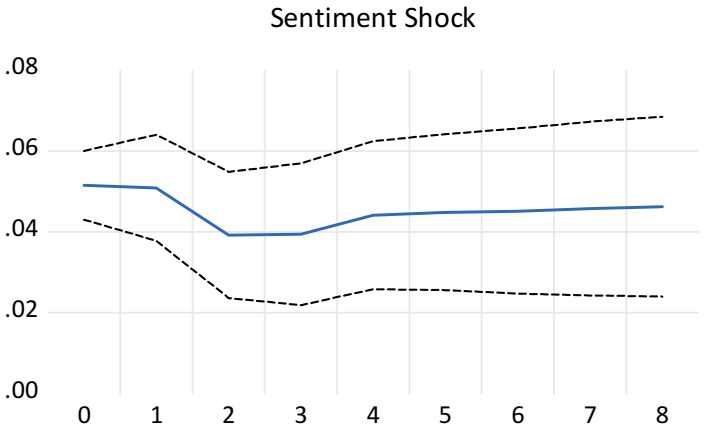

Global Liquidity Shock

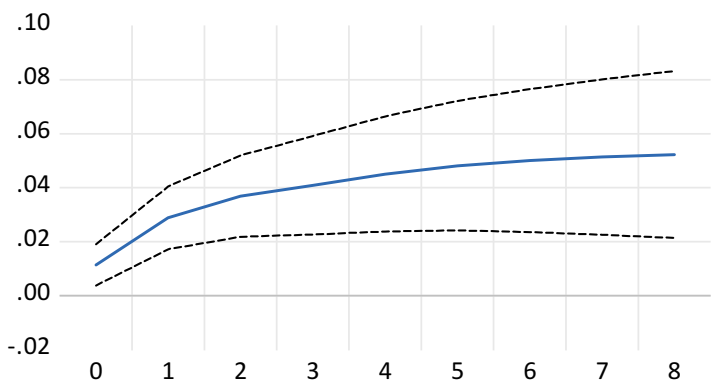

Credit Demand Shock

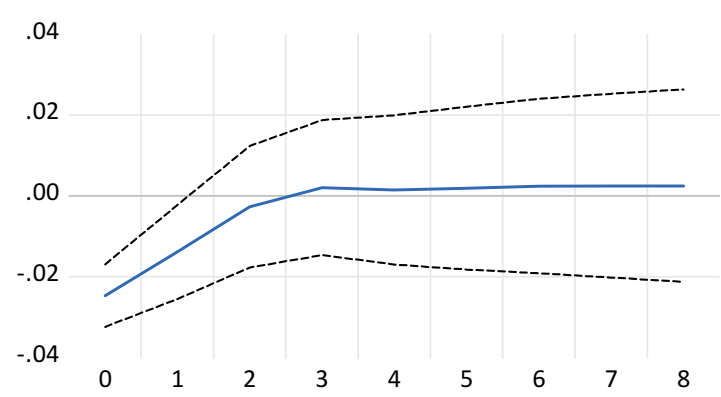


Technology Shock

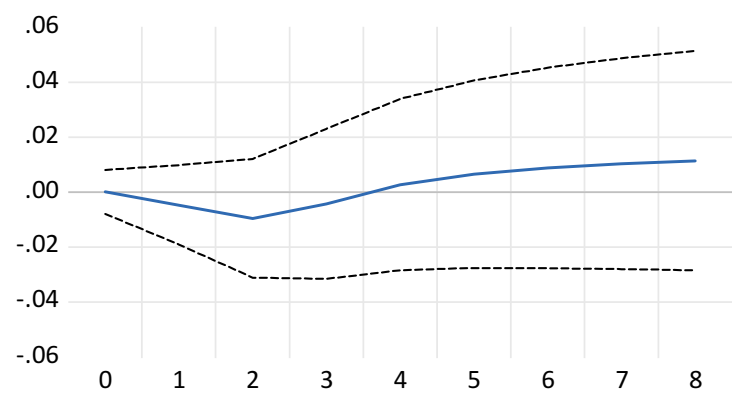

Risk Premium Shock

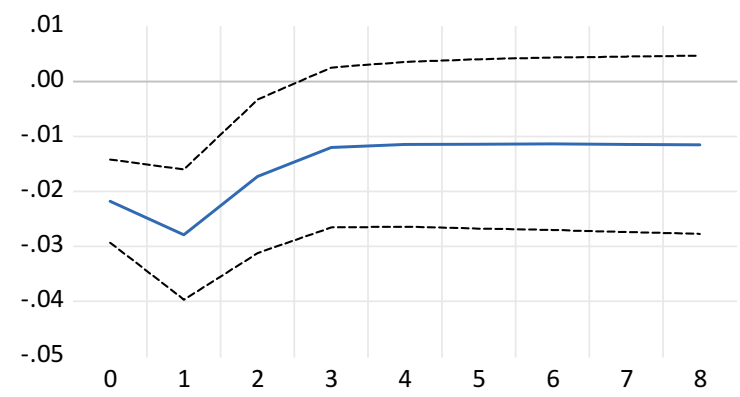

Direct Market Shock

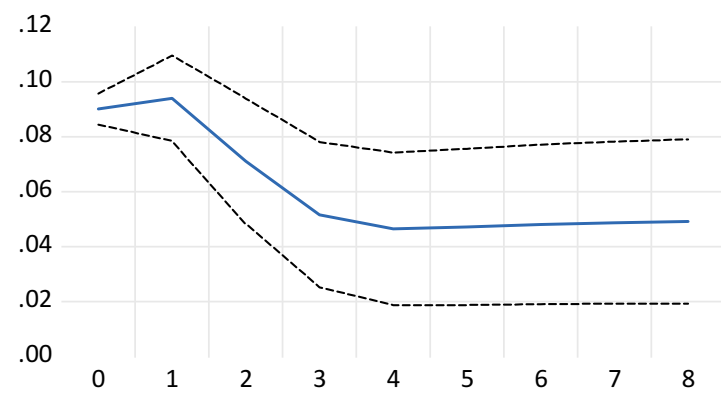

REIT Market Shock

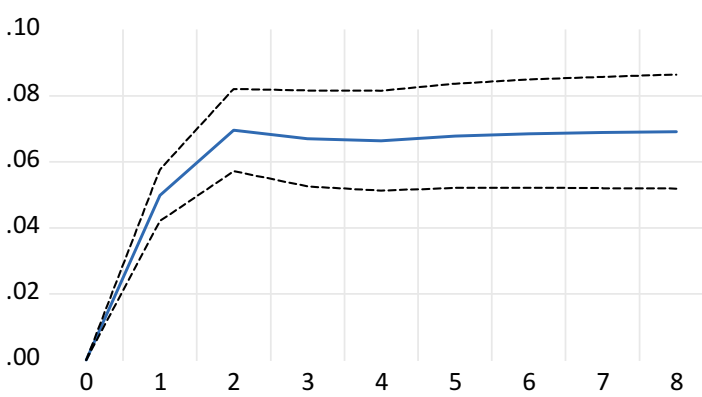

Figure A3. Accumulated impulse responses of direct real estate to one standard deviation shocks with $90 \%$ confidence bands based on Monte Carlo simulation with 500 draws.

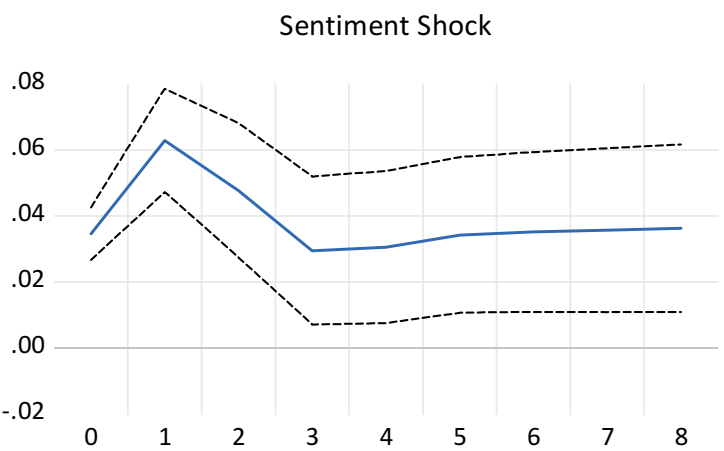

Global Liquidity Shock

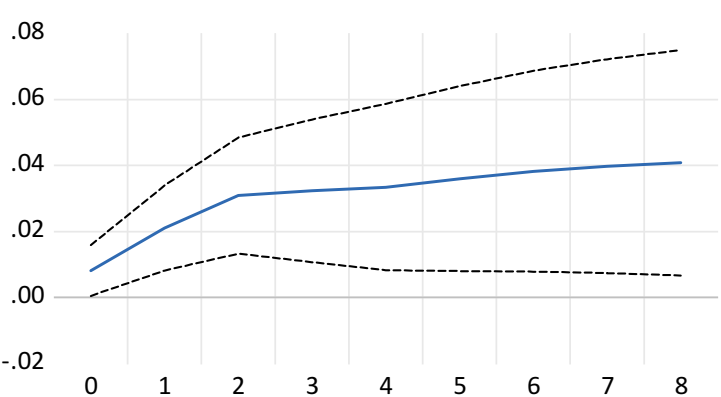

Credit Demand Shock

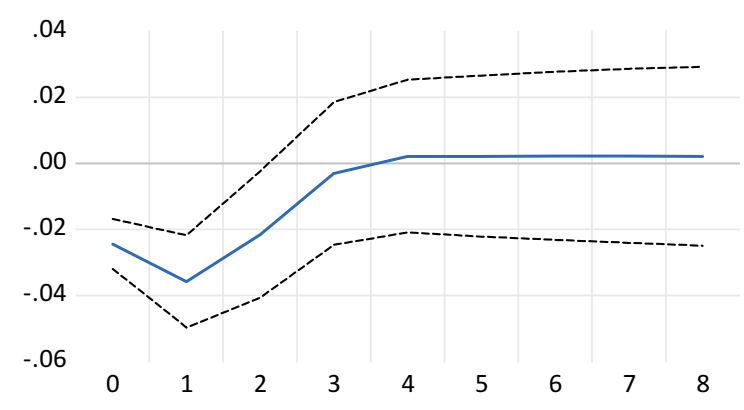

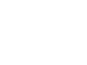

